\title{
Testicular Morphology of Adult Wistar Rats Treated with Rudgea viburnoides (Cham.) Benth. Leaf Infusion
}

\author{
Juliana Castro Monteiro ${ }^{1 *}$, Sérgio Luis Pinto da Matta $^{2}$, Fabrícia Souza Predes ${ }^{3}$ and \\ Tarcízio Antônio Rego de Paula ${ }^{4}$ \\ ${ }^{I}$ Departamento de Ciências Agrárias e Biológicas; Centro Universitário Norte do Espírito Santo; Universidade \\ Federal do Espírito Santo; 29932-540; São Mateus - ES - Brasil. ${ }^{2}$ Departamento de Biologia Geral; Universidade \\ Federal de Viçosa; 36571-000; Viçosa - MG - Brasil. ${ }^{3}$ Departamento de Biologia Estrutural e Funcional; Instituto \\ de Biologia; Universidade Estadual de Campinas; C. P.: 6109; 13083-863; Campinas - SP - Brasil. ${ }^{4}$ Departamento \\ de Veterinária; Universidade Federal de Viçosa; 36571-000; Viçosa - MG - Brasil
}

\begin{abstract}
The present study was carried out to investigate the effects of Rudgea viburnoides infusion on the body biometry and testicular morphometry and stereology of adult Wistar rats. Two groups received the infusion daily at the concentration of 3 or $6 \mathrm{mg} / \mathrm{mL}$ for 40 days. The control group received only water. Neither the biometrical parameters nor the tubular diameter and the height of the seminiferous epithelium showed any significant alterations in the treated animals. Leydig cells stereology did not show any significant alterations in the treated animals. These results indicated that $\mathrm{R}$. viburnoides did not cause alterations in body biometry and testicular morphometry.
\end{abstract}

Key words: Medicinal plant, Congonha-de-bugre, morphometry, stereology, Leydig cell

\section{INTRODUCTION}

Nowadays, most of the world's population has no access to the medical treatments and synthetic drugs, using traditional medicine because of its cheapest and easiest access. On the other hand, phytotherapic infusions and extracts commercialized in local markets have no proper quality control, which could be harmful to the users (Brandão et al. 1998). In Brazil, despite the widespread use of natural medicine, there is a lack of pharmacological and toxicological studies, which are essential to prove the plants efficacy.

Rudgea viburnoides (Cham.) Benth. (Rubiaceae), commonly known as "congonha-de-bugre", "cotócotó" and "chá-de-bugre", has been used for about three hundred years in Brazilian popular medicine (Young et al. 1998; Alves et al. 2000; Alves et al. 2004; Brandão et al. 2005). Various parts of the plant possess different medicinal properties: the leaves are used to treat the rheumatism, syphilis, dyspepsia, bladder and urinary tract disease, high blood pressure, etc. Recently, it has been reported useful for weight loss diets. The roots, barks and stems relieve the nocturnal sweating of tuberculous patients, stomach ulcers and rheumatism, also being used as a blood depurative. The ripe fruit rinds exhibited a moderate antifungal activity against Cladosporium cladosporioides (Moreira 1983; Young et al. 1998; Alves et al. 2004).

Recent studies with $R$. viburnoides leaf ethanolic

*Author for correspondence: julianacmonteiro@yahoo.com.br 
extract did not cause acute toxic or mortality in the animals after the treatment (Pucci et al. 2007). However, the leaf infusion decreased the plasma triacylglycerol of Wistar rats, which was not related to a reduction in food consumption but correlated to microscopic changes in fatty deposits within the liver (Monteiro et al. 2009).

The present work aimed to investigate the effects of $R$. viburnoides leaf infusion on adult Wistar rat testicular parenchyma.

\section{MATERIAL AND METHODS}

\section{Infusion preparation}

The leaves of $R$. viburnoides were collected in Congonhas (Minas Gerais - Brazil) in May, 2002. This species was identified by Gilmar Edilberto Valente, authenticated and deposited in the Herbarium VIC at the Department of Plant Biology (Federal University of Viçosa, Brazil) under the number 26728. The leaves were shadedried and used to prepare the infusion by pouring a liter of boiling water over them. The solution was allowed to steep for 20 minutes and filtered using filter paper. The product was an infusion of $3.0 \mathrm{mg}$ extract per $\mathrm{ml}(0.3 \% \mathrm{w} / \mathrm{v})$ and a yield of $32.153 \%$ $(\mathrm{w} / \mathrm{w})$ in terms of initial crude dry weight plant materal.

\section{Animals}

Thirty adult Wistar rats, 100-days-old and weighing 230-270g were obtained from the Department of Nutrition and Health Bioterium (Federal University of Viçosa, Viçosa, MG, Brazil) and maintained in individual cages in 12hL: $12 \mathrm{hD}$ conditions. The animals used in the experiment were kept and handled in accordance to the Ethical Principles for Animal Research established by the Brazilian College for Animal Experimentation (COBEA). The animals were pelleted-fed standard rat food ad libitum.

\section{Treatment}

All the animals received water and the infusion in water bottles attached to the outside of the cage for 40 days. The control group received only water (200 mL). G-3 and G-6 received daily $200 \mathrm{~mL}$ of leaf infusion of $R$. viburnoides at concentrations of 3 and $6 \mathrm{mg} / \mathrm{ml}$, respectively. The dosages were selected to mimic the popular medicinal use. The daily consumption was measured.

\section{Light microscopy}

The animals were anesthetized with ether and the abdomen and thoracic cavities opened and were subsequently perfusion-fixed by whole body perfusion, based on the method proposed by Sprando (1990). The testis, epididymis and seminal vesicle were dissected out and immediately placed in the same fixative solution. Testis tissue was post fixed for $24 \mathrm{~h}$ in $2.5 \%$ glutaraldehyde in phosphate buffer and prepared for embedding in glycol methacrylate (Historesin ${ }^{\circledR}$, Leica), following the routine technique. Subsequently, $4 \mu \mathrm{m}$ thick sections were obtained and stained with toluidine blue-sodium borate.

\section{Biometric parameters}

The organs were carefully freed from the surrounding fat and connective tissue and weighed. One testis was dissected to remove the tunica albuginea. The gonadosomatic index $(\mathrm{GSI}=$ $(\mathrm{TW} / \mathrm{BW}) \times 100)$, which showed the percentage of body mass allocated to the testis was calculated based on body (BW) and testicular (TW) weights.

\section{Volume and volumetric density (\%) of the testis compartments}

The volumetric densities were determined by using a 494-intersection grid placed in the ocular lens of an Olympus BX-50 light microscope. Nine thousand points were counted for each animal at 400X magnification, covering seminiferous epithelium, nucleus and cytoplasm of Leydig cells, blood vessels, lymphatic space and connective tissue. The volume of each component of the testis was determined as the product of the volumetric density and testicular volume. For subsequent morphometric calculations, the specific gravity of the testis tissue was considered to be 1.0. To obtain a more precise measurement of the testis volume, the testicular albuginea was excluded from the testis weight (França et al. 2000).

Tubular diameter, seminiferous epithelium height and seminiferous tubules length

The tubular diameter and the seminiferous epithelium height were measured with a $100 \mathrm{X}$ magnification, using the software Image Pro-Plus. Thirty tubular profiles that were round or nearly round were measured for each animal. The total length of the seminiferous tubules (in meters) per testis and per gram of testis was obtained by the formula $\mathrm{TL}=\mathrm{VST} / \pi \mathrm{R}^{2}$, where $\mathrm{TL}=$ seminiferous 
tubule length; VST $=$ the volume of the seminiferous tubule and $\mathrm{R}=$ seminiferous tubule diameter/2.

\section{Leydig cell stereology}

The volume of each Leydig cell was obtained from the nucleus volume and the proportion between the nucleus and cytoplasm. To obtain the nucleus volume, the diameters of 30 spherical nuclei showing evident nucleoli were measured for each animal. Leydig cell nuclear volume was expressed in $\mu \mathrm{m}^{3}$ and obtained by the formula $(4 / 3) \pi \mathrm{R}^{3}$, where $\mathrm{R}=$ nuclear diameter $/ 2$. To calculate the proportion between the nucleus and cytoplasm, a 121-intersection grid was placed in the ocular lens of an Olympus BX-50 light microscope, using 1000X magnification. Three thousand points situated over the Leydig cells were counted for each animal. The number of Leydig cells per testis was estimated from the Leydig cell's individual volume and the volume occupied by the Leydig cells in the testis parenchyma.

\section{Statistical analysis}

All data were presented as the mean \pm SEM and analyzed via ANOVA (Duncan test). The significance level was $P<0.05$.

\section{RESULTS}

The animals ingested $50 \mathrm{ml}$ of tea and water per day on average. The weights of body, testis, tunica albuginea and seminal vesicle, as well as the gonadosomatic index (GSI) of $R$. viburnoidestreated animals were not significantly different from any of the groups studied (Table 1). Also, the tubular diameter height and length of the seminiferous epithelium were not statistically different from the control (Table 1). The morphometric measurements of the volumetric density and testicular volume were not statistically different from the control (Table 1). The morphometric measurements of the volumetric density and testicular volume components were similar to the control group (Table 2). The Leydig cell stereology is presented in the Table 3. These parameters did not alter after the treatments, No Any alteration in the testicular morphology was observed in the treated-groups (Fig. 1).

Table 01- Biometric data and testis morphometric measurements of the adult Wistar rats treated with leaf infusion of $R$. viburnoides.

\begin{tabular}{|c|c|c|c|}
\hline Parameters & Control & G-3 & G-6 \\
\hline Body weight (g) & $239.03 \pm 6.59$ & $242.66 \pm 6.91$ & $241.06 \pm 4.56$ \\
\hline Testis weight $(\mathrm{g})^{\mathrm{a}}$ & $1.24 \pm 0.08$ & $1.25 \pm 0.07$ & $1.28 \pm 0.05$ \\
\hline Gonadosomatic index $(\%)$ & $1.04 \pm 0.05$ & $1.03 \pm 0.04$ & $1.07 \pm 0.03$ \\
\hline Testicular albuginea weight $(\mathrm{g})$ & $0.10 \pm 0.01$ & $0.10 \pm 0.01$ & $0.10 \pm 0.01$ \\
\hline Seminal vesicle weight $(\mathrm{g})^{\mathrm{b}}$ & $0.61 \pm 0.05$ & $0.61 \pm 0.04$ & $0.50 \pm 0.04$ \\
\hline Tubular diameter $(\mu \mathrm{m})$ & $321.59 \pm 4.23$ & $322.84 \pm 4.04$ & $312.94 \pm 6.22$ \\
\hline Epithelium height $(\mu \mathrm{m})$ & $113.57 \pm 2.52$ & $123.22 \pm 3.72$ & $107.44 \pm 11.77$ \\
\hline Total tubular length (m) & $12.89 \pm 0.68$ & $13.09 \pm 0.52$ & $14.28 \pm 0.57$ \\
\hline Total tubular length per gram testis (m) & $10.87 \pm 0.35$ & $10.93 \pm 0.35$ & $11.61 \pm 0.47$ \\
\hline
\end{tabular}

Values are mean \pm S.E.M. $(n=10)$. Difference not statistically significant $(\mathrm{p}>0.05)$.

Control: distilled water, G-3: R. viburnoides $3 \mathrm{mg} / \mathrm{ml}$; G- 6 : $R$. viburnoides $6 \mathrm{mg} / \mathrm{ml}$

${ }^{\mathrm{a}}$ value corresponding to the average of the right and left testis weight.

${ }^{\mathrm{b}}$ value corresponding to the seminal vesicle weight, minus coagulation gland weight.

Table 02 - Volume $(\mathrm{mL})$ and volumetric density (\%, in parentheses) of the testis compartments in adult Wistar rats treated with leaf infusion of $R$. viburnoides.

\begin{tabular}{lccc}
\hline Parameters & Control & G-3 & G-6 \\
\hline Seminiferous tubule & $1.03 \pm 0.05(86.49)$ & $1.07 \pm 0.03(89.03)$ & $1.09 \pm 0.02(88.47)$ \\
Interstitial space & $0.16 \pm 0.02(13.51)$ & $0.13 \pm 0.02(10.97)$ & $0.14 \pm 0.02(11.53)$ \\
$\quad$ Lymphatic space & $0.09 \pm 0.01(8.05)$ & $0.06 \pm 0.01(5.21)$ & $0.07 \pm 0.01(6.02)$ \\
$\quad$ Blood vessels & $0.02 \pm 0.01(1.44)$ & $0.01 \pm 0.00(1.06)$ & $0.02 \pm 0.00(1.30)$ \\
Connective tissue & $0.02 \pm 0.01(2.09)$ & $0.04 \pm 0.01(2.99)$ & $0.03 \pm 0.01(2.10)$ \\
Leydig cell & $0.02 \pm 0.00(1.93)$ & $0.02 \pm 0.00(1.70)$ & $0.03 \pm 0.00(2.11)$ \\
\hline
\end{tabular}

Values are mean \pm S.E.M. $(n=10)$. Difference not statistically significant $(\mathrm{p}>0.05)$.

Control: distilled water, G-3: R. viburnoides $3 \mathrm{mg} / \mathrm{ml}$; G-6: $R$. viburnoides $6 \mathrm{mg} / \mathrm{ml}$. 
Table 03 - Stereology of Leydig cells of adult Wistar rats treated with leaf infusion of R. viburnoides.

\begin{tabular}{lccc}
\hline Leydig cell & Control & G-3 & G-6 \\
\hline Nuclei diameter $(\mu \mathrm{m})$ & $7.17 \pm 0.20$ & $7.21 \pm 0.09$ & $6.98 \pm 0.21$ \\
Individual volume $\left(\mu \mathrm{m}^{3}\right)$ & $654.25 \pm 73.11$ & $685.77 \pm 40.81$ & $530.08 \pm 52.08$ \\
Nuclei volume $\left(\mu \mathrm{m}^{3}\right)$ & $197.49 \pm 16.50$ & $197.05 \pm 7.53$ & $182.30 \pm 15.16$ \\
Cytoplasmic volume $\left(\mu \mathrm{m}^{3}\right)$ & $456.76 \pm 58.65$ & $488.72 \pm 36.64$ & $347.78 \pm 38.33$ \\
Number/testis $\left(10^{6}\right)$ & $36.9 \pm 4.10$ & $31.2 \pm 5.00$ & $49.1 \pm 4.50$ \\
Number/g testis $\left(10^{6}\right)$ & $31.1 \pm 3.10$ & $25.8 \pm 4.00$ & $39.8 \pm 3.30$ \\
\hline
\end{tabular}

Values are mean \pm S.E.M. $(n=10)$. Difference not statistically significant $(\mathrm{p}>0.05)$.

Control: distilled water, G-3: R. viburnoides $3 \mathrm{mg} / \mathrm{ml}$; G-6: R. viburnoides $6 \mathrm{mg} / \mathrm{ml}$.
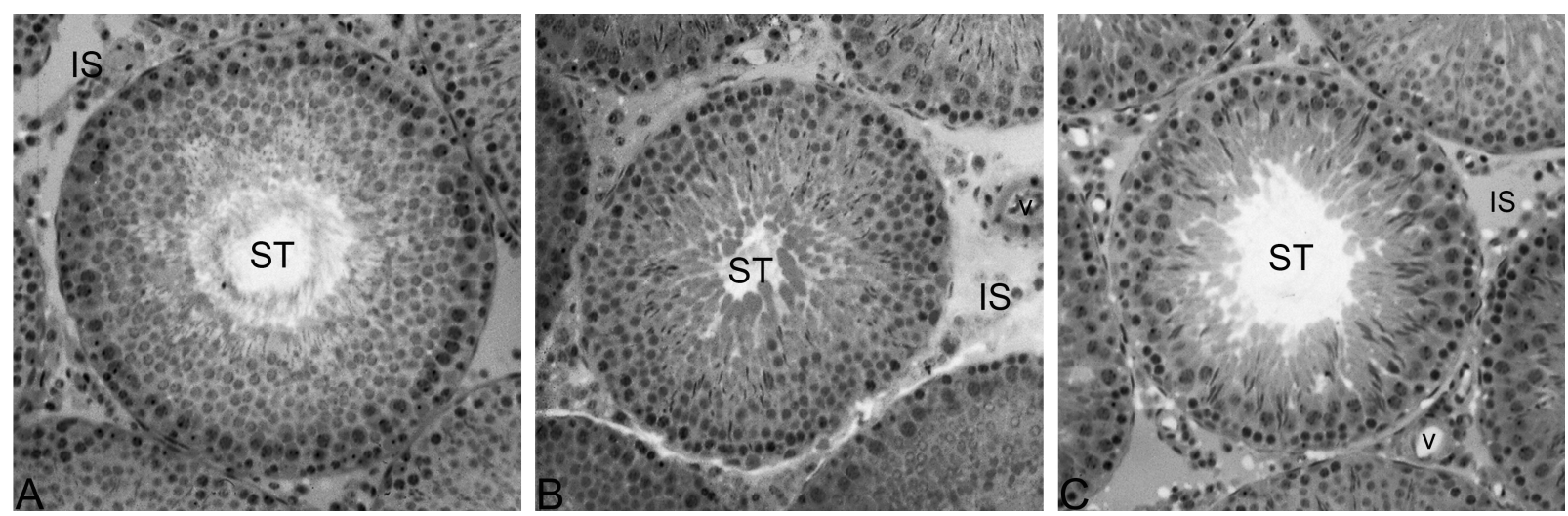

Figure 1 - Normal testicular tissue of Wistar rats treated with different concentrations of $R$. viburnoides leaf infusion. A- control group; B- G-3 (3mg/ml); C- G-6 (6mg/ml). STseminiferous tubule, IS- interstitial space, v- blood vessel. Toluidine blue/1\% sodium borate. $200 \mathrm{X}$.

\section{DISCUSSION}

The present study was undertaken to evaluate the effects of different concentrations of leaf infusion of $R$. viburnoides in relation to the biometry and testicular morphometry of adult Wistar rats. The results showed the non-toxic effect of the compounds tested, as shown by the unaltered body weight and plasma clinical parameters (Monteiro et al. 2009), which indicated normal functioning of vital organs, including androgen dependent accessory reproductive glands.

Sperm production is highly correlated with the testicular weight. Testis weight generally establishes the normalcy of testis, enabling experimentally induced changes in testicular size and potential spermatozoa production to be assessed (França and Russell 1998). In the present study, there were no alterations of testicular weight, suggesting that sperm production and fertility were not affected.
It is well established that androgens are the major regulators of growth, structure and functions of accessory sex organs (Creasy 2001). The different doses of $R$. viburnoides infusion did not alter the weight of the seminal vesicle. Under the present experimentation model, results indicated that this infusion did not cause alterations in the testosterone levels in the treated rats.

Functionally, the mammal testis is divided in two basic compartments: the tubular (or spermatogenic) and the intertubular (or androgenic) portions. In rats, 90\% (volume density) of testicular parenchyma is occupied by the seminiferous tubules and $10 \%$ by interstitium (Russell and França 1995; Kim and Yang 1999).

In this work, different values were found for these compartments, but the volumetric density values in the treated animals were similar to the control, which raised the hypothesis that the infusion of $R$. viburnoides did not alter the volume or the volume density of testicular components (Fig. 1). There 
are several reasons for the variability seen in the volume density of the testicular components. These include the preparation methods that can result in tissue shrinkage, the morphometric techniques employed and the amount of sampling used by different investigators, which may vary considerably. The interpretation of images in which the quality varies inevitably leads to different results (Russell and França 1995).In rats, the Leydig cells represent $3 \%$ of the testicular parenchyma and the number of cells per testis is variable in the data available from previous studies. Russell and França (1995) found 33.6 x $10^{6}$ cells per testis in adult rats. On the other hand, Kim and Yang (1999) found $22 \times 10^{6}$ cells per testis and Ichihara and collaborators (1993) found $22 \times 10^{6}$ cells per gram of testis in adult rats. In the present study, the number of cells in control and treated animals was similar to the number of cells cited by Russell and França (1995).

Therefore, the present findings suggested that leaf infusion of $R$. viburnoides, in the doses and for the period during which it was administered, did not cause alterations in body biometry and testicular morphometry.

\section{ACKNOWLEDGEMENTS}

The authors would like to acknowledge Dra. Heidi Dolder (Department of Cell Biology UNICAMP) for correcting the English.

\section{REFERENCES}

Alves RMS, Stehmann JR, Isaias RMS, Brandão MGL. Caracterização botânica equímica de Rudgea viburnoides (Cham.) Benth., (Rubiaceae). Rev Bra Farm. 2004; 14: 49-56.

Alves TMA, Silva AF, Brandão M, Grandi TSM, Smânia EFA, Smânia-Júnior A, Zani CL. Biological Screening of Brazilian Medicinal Plants. Mem Inst Oswaldo Cruz. 2000; 95: 367-73.

Brandão MGL, Fernandes IN, Santana FC, Santana PC, Bernardes L. Circuito de plantas medicinais e aromáticas de Belo Horizonte. In: $8^{\circ}$ Encontro de Extensão da UFMG. 2005; Belo Horizonte, Brazil.

Brandão MGL, Freire N, Vianna-Soares CD. Vigilância de fitoterápicos em Minas Gerais. Verificação da qualidade de diferentes amostras comerciais de camomila. Cad Saude Pub. 1998; 14: 613-16.
Creasy DM. Pathogenesis of male reproductive toxicity. Toxicol Pathol. 2001; 29: 64-76.

França LR, Russell LD. The testis of domestic mammals. In: Martinez-Garcia F, Regadera J, Editor. Male reproduction. A multidisciplinary overview. Madrid: Churchill Livingstone; 1998. p.192-219.

França LR, Silva VA, Chiarini-Garcia H, Garcia SK, Debeljuk L. Cell proliferation and hormonal changes during postnatal development of the testis in the pig. Biol Reprod. 2000; 63: 1629-36.

Ichihara I, Kawamura H, Pelliniemi LJ. Ultrastructure and morphometry of testicular Leydig Cell. Tissue Res. 1993; 271: 241-55.

Kim IS, Yang HH. Morphometric study of the testicular interstitium of the rat during postnatal development. Korean J Anat. 1999; 32: 849-58.

Monteiro JC, Matta SLP, Predes FS, Oliveira TT. Liver morphology and morphometry and plasma biochemical parameters of Wistar rats that received leaf infusion of Rudgea viburnoides Benth. (Rubiaceae). Braz Arch Biol Technol. 2009; 52: 40712.

Moreira F. As plantas que curam. São Paulo: Hemus; 1983.

Pucci LL, Santos A, Cunha LC, Valadares Mc, Paula J, Paula JR. Avaliação da toxicidade aguda método de classes do extrato etanólico de Rudgea viburnoides (Cham.) Benth., (Rubiaceae). Rev Elet Farm. 2007; 4:72-4.

Russell LD, França LR Building a testis. Tissue Cell. 1995; 27:129-47.

Sprando RL. Perfusion of the rat testis through the heart using heparin. In: Russell LD, Ettlin R, Sinha-Hikim AP, Editor. Histological and Histopathological Evaluation of the Testis. Clearwater: Cache River Press; 1990. p.277-80.

Young MC, Araujo AF, Da Silva CA, Lopes, MN, Trevisan LM, Bolzani VS. Triterpenes and saponins from Rudgea viburnoides. J Nat Prod. 1998; 61:93638.

Received: December 22, 2010; Revised: March 24, 2011; Accepted: October 07, 2011. 